\title{
Rural tourism marketing: Lavender tourism in Turkey
}

\author{
Fatma Handan Giray ${ }^{*}$ (iD Bektaş Kadakoğlu ${ }^{1}$ (iD Fatmagül Çetin $^{1}$ (iD \\ Abdou Gafarou Abdoulaye Bamoi ${ }^{1}$ iD
}

${ }^{1}$ Department of Agricultural Economics, Faculty of Agricultural Sciences and Technology, Isparta University of Applied Sciences (ISUBU), 32260 Çünür/ISPARTA TURKEY. E-mail: handangiray@isparta.edu.tr. *Corresponding author.

\begin{abstract}
This study aimed to comprehend rural tourism marketing through the visitors' eyes and discuss its sustainability. What makes rural tourism marketing more sophisticated and complex is that it is a service marketing, associated with agricultural activities, natural conditions and rural areas, and the main providers have no experience in rural tourism or service marketing. The study investigated perception of visitors in a small village, Kuyucak, in the Southwest part of Turkey, where rural tourism based on lavender production has recently developed. Results of the analysis of 175 questionnaires completed by visitors online showed that more than half of the respondents had heard and got information about the village via social media. Although, the main purpose of their visit was stated as nature/rural experience and recreation/holiday, the primary motivation of the majority was taking and sharing photos via social media tools. Appearance of lavender and previous social media sharing are very important determinants in the decision-making and expectations of visitors. Results of the factor analysis showed that two components composed of the variables regarding pre-visit perception and the physical conditions of the village together explain sixty-five per cent of the overall satisfaction. The most important component in decision making of visitors was found their perception before visiting, which means that what they expected to see was more important than what they actually saw, which was represented by visitors'satisfaction. Making visitors experience their pre-visit perception will contribute to the sustainability of rural tourism activities benefiting the area.
\end{abstract}

Key words: rural tourism marketing, visitors' perception, visitors'motivation, marketing strategy, lavender, Kuyucak.

\author{
Marketing do turismo rural: Turismo lavanda na Turquia
}

RESUMO: Este estudo teve como objetivo compreender o marketing do turismo rural através dos olhos dos visitantes e discutir sua sustentabilidade. O que torna o marketing do turismo rural mais sofisticado e complexo é que ele é um marketing de serviços, associado a atividades agrícolas, condições naturais e áreas rurais, e os principais provedores não têm experiência em turismo rural ou marketing de serviços. O estudo investigado a percepção de visitantes em uma pequena aldeia, Kuyucak, no sudoeste da Turquia, onde o turismo rural baseado na produção de lavanda se desenvolveu recentemente. Os resultados da análise de 175 questionários preenchidos pelos visitantes online mostraram que mais da metade dos entrevistados ouviram e receberam informações sobre o vilarejo pelas midias sociais, e embora o objetivo principal de sua visita tenha sido declarado como natureza experiência rural e recreação feriado, a principal motivação da maioria foi tirar e compartilhar fotos através de ferramentas de mídia social. O surgimento da lavanda e o compartilhamento prévio de mídias sociais são determinantes muito importantes na tomada de decisões e expectativas dos visitantes. Os resultados da análise fatorial mostram que dois componentes compostos pelas variáveis relativas à percepção pré-visita e às condições físicas da aldeia, juntos, explicam $65 \%$ da satisfação geral. O que foi considerado interessante foi o componente sobre a percepção deles antes de visitar, o que significa que o que eles esperavam ver era mais importante do que o que eles realmente viram e encontraram o que foi representado pelo componente em evidências fisicas sobre a satisfação dos visitantes. Fazer com que os visitantes experimentem sua percepção pré-visita contribuirá para a sustentabilidade das atividades de turismo rural e seus beneficios na área.

Palavras-chave: marketing de turismo rural, percepção dos visitantes, motivação dos visitantes, estratégias de marketing, lavanda, Kuyucak.

\section{INTRODUCTION}

The study investigated rural tourism marketing in the lavender area in Kuyucak village in the district of Keçiborlu in Isparta. Isparta is a small province located in the Southwest Mediterranean Region of Turkey. The marketing concept is described in marketing mix as any strategy adopted by a company or enterprise or economic initiation which depends on a combination of goods (products or services) availability, promotion or communication with customers (in our case visitors) and prices. Findings of previous studies stated that marketing in rural tourism should be used as a means for developing strategic goals of rural tourism destinations, such as prosperity in the 
long run, visitors' satisfaction, profit maximization, tourism season extension, and neutralization of the negative social and environmental impact of tourism. (MIHAILOVIĆ \& MORIC, 2012). Availability of an enormous range of communication tools and visibility of promotion activities increases the importance of social networking, the media, internet and marketing influencers, attracting people to visit rural areas and making everything very dynamic. What we have observed in our study area is mass promotion, a rapid and stereotypical development, and lack of involvement of other marketing elements in the strategies, such as availability and development of products and services, all of which threatens sustainability. This makes social networking, media, internet and marketing influencers more important in attracting people to visit rural areas.

The study area, Kuyucak, is a village with a population of 250 located $47 \mathrm{~km}$ from the provincial capital of Isparta. Lavender production started in the village in the1970s. Initially there were 30 families with only 15 plant roots. Relatively easy cultivation and modest land and climate condition requirements encouraged farmers to cultivate lavender. Not only the study area but also the country as a whole has increased its lavender plantation in the last decade. Before 2000, the study area was producing more than $90 \%$ of total lavender production of the country on a production area of about 50 ha, whereas now the total production area is more than 300ha in the study area and approaching 700ha in Turkey (TURKSTAT, 2018), thanks to an increasing demand for aromatic plants and the high profitability of lavender (GUL et al., 2016; BOZKIRAN \& GIRAY, $2014)$. The village now accounts for over $50 \%$ of the lavender production of the country (BOZKIRAN \& GIRAY, 2016). However, reputation of the area as the "Lavender Scented Village" throughout the country is quite new and originates not through its agricultural or industrial value but from value added by rural tourism. It was started only three years ago (in 2015 and 2016) by local actors as a grassroots movement and is supported through a national program entitled "The future is in tourism" which was initiated by a private company, local authorities and international founders in 2007 (UNDP, 2018). Today, the area receives a large number of tourists from many places. In only three years, the number of the tourists coming to Isparta province has increased by $5.44 \%$ thanks to people visiting the lavender areas in Kuyucak (BASARAN, 2017). While villagers and visitors are happy with this development based mostly on lavender's attractive image, color and aroma, some challenges have also occurred because of the nature of rural tourism. We wanted to see what was happening in the area, how it had become a phenomenon in only three years, whether it was a true success story or just a quick fad which would soon disappear, and what was going to be done to make it sustainable on the basis of marketing theories adapted to rural tourism marketing and visitors' motivation and satisfaction factors, and their expectations. It is important because the newest concept of marketing has been increasingly seen as managing a profitable relationship with customers who are visitors in rural tourism marketing and who are the basic setting for success (MIHAILOVÍC \& MORIC, 2012). In this context the purpose was to investigate the function of marketing concept in rural tourism development with particular attention to visitors' perception and develop recommendations in order to sustain rural tourism activities in the region and reply the research questions which were whether it is a true success story or not and what should be done to make it sustainable in the future. While the empirical part of the study focused on visitors' perception, in other saying demand side, results provided recommendations to supply side of rural tourism marketing through a marketing mix developed based on visitors' opinions.

\section{A heuristic approach for exploring the research context SAXENA (2016) defines rural tourism} marketing as "a variegated phenomenon linked intricately with how rurality is experienced and shaped by actors' enterprises and a broad array of sociocultural, political, economic and material processes and practices." Considering this complexity and the benefits which all the actors can derive from rural tourism, the issue of the marketing of rural tourism needs to be studied (AITHAL \& ANIL, 2008). It is complex because rural tourism is a specific type of tourism which takes its features from the rural and agricultural sector. This is why it is so associated with agricultural activities and rural areas, making the seasonal character of the demand in tourism (MIHAILOVIĆ \& MORIC, 2012) and creating a dilemma between marketing and rural tourism. Rural tourism marketing is more challenging than marketing tourism in general (PUAT MAT SOM et al., 2010). Marketing is expected to generate, diversify and extend the life of activities, while one of the main roles of marketing philosophy in rural tourism is to protect the specific features of rural areas and activities which are the raison d'être of rural tourism. The aim of marketing is to make the sector successful, but the rural tourism sector cannot enjoy 
the benefits of being too successful because success will change and/or destroy the nature of the product and the distinctive character of the environment (MIHAILOVİ́ \& MORIC, 2012; GILBERT, 1989). Based on this argument, MIHAILOVİC \& MORIC (2012) defined the role of marketing philosophy in rural marketing as defining the guidelines for image creation and protection, through a convenient strategic marketing plan, in order to protect the longterm interests of an area.

The basic elements of marketing do not differ in rural tourism, but rural tourism promotional strategies require a niche appeal rather than a mass appeal (PUAT MAT SOM et al., 2010). However, there is a hidden risk, what appeared to be niche markets may in reality be vulnerable parts of a mass market (ROBERTS \& HALL, 2004). At this stage, there is a need to differentiate between niche and segment in order to provide good marketing.

With good marketing in rural tourism, it is possible to obtain considerable potential economic value including economic diversification, long-term economic stability, a trend to higher spending and a longer stay in rural areas, a demand for local goods and services, infrastructure development, and an increase in farmers' income (PAVEL, 2013).

However, this is neither simple nor easy. Rural tourism marketing should not be seen simply as advertising and promotion or printing leaflets, but as a means to achieve the development of the strategic goals of rural tourist destinations for economic, social and environmental purposes, from visitors' satisfaction to the extension of the tourist season and longterm prosperity (MIHAILOVIĆ \& MORIC, 2012). However, results of previous studies showed that the majority of suppliers in rural tourism dedicated very little of their time to developing marketing activities (PATO \& KASTENHOLZ, 2017). This applies not only to business practices but also to academic studies. As PATO \& KASTENHOLZ (2017) stated, despite its importance, rural tourism marketing has not received sufficient or continuous attention except in some remarkable studies. This is defined as "paucity" by GILBERT (1989) and "spares" by CAI et al. (2008) in rural tourism marketing.

Marketing philosophy, marketing mix, marketing structures, marketing strategies, positioning strategies, marketing implementation, niches, destination image, segmentation, activity patterns, motivation and satisfaction are prominent subjects in rural tourism marketing. There are also few studies on very specific topics such as using colors in rural tourism marketing strategies, where the emotional effects of a combination of violet, the color of lavender, and other colors are described as follows: violet with green and orange is enjoyable; violet with yellow is doubtful; violet with red, purple and blue is unpleasant (DONCEAN, 2013). More recent studies address the effects of social media on visitors and green marketing tools in rural tourism. Although, there are overlaps among them in the literature regarding rural tourism, marketing has been classified into three groups in order to develop an appropriate approach for data collection and analysis and to make use of results of previous studies. For the purposes of this study, marketing mix, visitor's motivation and satisfaction and social media in rural marketing strategies are reviewed below.

\section{Marketing mix}

Classic marketing mix, known as $4 \mathrm{Ps}$, is a theory proposed by MCCARTHY (1960) which has been adapted to tourism marketing in order to maximize economic benefits through attracting people who become visitors and conduct tourism consumption, for instance, promotion of a destination in newspapers and networks, attracting consumers with competitive prices, and making products ready in more places through multiple channels (JIA \& XIAOBING, 2017). In addition to the classic 4Ps (product, price, place and promotion), there are studies that discuss additional Ps in marketing mix. For example, people-centric new Ps inspired by consumer images are discussed in the marketing of niche products, as follows: profit, pause, pleasure and principle (DAGEVOS, 2009). When it comes to service marketing where rural tourism is concerned, it is suggested that the 4Ps strategy should be extended to 7Ps or 8Ps. Based on a study by BOTTEN \& MCMANUS (1999), ESMAILI et al. (2017) express service marketing variables as seven strategic factors (7Ps) with an additional 3 Ps, as follows: physical evidence, people and process, or 8Ps including political and social situation (ESMAILI et al., 2017). Marketing mix model with these elements is studied in order to evaluate and prioritize the effective indices in rural tourism marketing as affecting factors of loyalty to a tourism destination (GHADIRI et al., 2013; ESMAILI et al., 2017). According to a study conducted in the town of Khalkhal in Iran, the elements of promotion, people and price are ranked respectively and the distribution (place) element seems to have no effect on the lack of activities related to the distribution of tourist attraction in the loyalty to the region (ESMAILI et al., 2017). Through an appropriate 
marketing mix, it is possible to develop strategies to increase the number of visitors and improve rural tourism sector, and these elements can also play a valuable role in creating a positive state of visitors' minds (SERYASAT et al., 2014). An appropriate design of the marketing mix dimensions also helps to achieve more competitive rural territories and conditions for the settlement of active population segments as complementary objectives (DINIS, 2006; PATO \& KASTENHOLZ, 2017).

\section{Visitor motivation and satisfaction}

Rural tourism marketing studies pay particular attention to a visitor's motivation and satisfaction. As it is a very specific and relatively new pattern of tourism, and because tourist profiles and people who deal with rural tourism have no experience in service marketing, it is important to know visitors' motivations and satisfaction. In the newest concept of marketing, much attention is paid to managing profitable relationships with customers, and this is seen as a basic setting for the success of modern managers (MIHAILOVÍC \& MORIC, 2012), which makes it crucial to know visitors' motivation and satisfaction factors. This is why visitors' motivation and satisfaction studies are important to rural tourism providers in adjusting their supply according to the demand of visitors. For instance, a study in Portugal by ANTUNES et al. (2015) identified three factors related to basic amenities, sport and nature which can serve as a support to strategic decision making. Another study in Portugal was conducted through an online questionnaire targeting not only a certain region's visitors but also the residents of Portugal who participated in rural tourism (KASTENHOLZ et al. 2017). Satisfaction of the participants was measured according to factors named as education, entertainment, escapism, aesthetic, arousal and memory. Results showed that aesthetic realm was prominent while the escapist dimension was the least important, and education and entertainment fell in between. The authors concluded that "aesthetic experience dimension stands out as impacting significantly on both arousal and memory, and indirectly on satisfaction", and also stated that "the aesthetic appreciation, particularly of nature and landscape, is a major theme in other rural tourism studies". A Korean case study by PARK \& YOON (2009) reported that the most preferred activities in rural tourism were ecological activity, agricultural experience and gastronomy, while the least preferred activities were sport, museum visits and hunting. DEVESA et al. (2010) analysed the relationship between motivation and visitor satisfaction in a rural destination in Spain. The authors classified four market segments of visitors, namely "visitors looking for tranquillity, rest and contact with nature", "cultural visitors", "proximity-gastronomic and nature visitors" and "return tourist". According to the results, visitors' satisfaction depended on their relation to the reasons that motivated or determined the trip. They also reported that there are certain elements which function independently from visit motivation and strongly affect global satisfaction ("general satisfiers"). Among the factors affecting visitors' loyalty to a tourism destination, mental image of the destination has also been described as having a significant and positive affect on the perceived value and satisfaction of the destination (DEHGHANI et al., 2013; ESMAILI et al., 2017).

The reason why identification of these elements is important is that they are very useful in the direction of marketing planning for destination. Previous studies on the motivation and satisfaction of visitors to rural areas showed that effective factors vary from one to another. There is not only variation between countries but also within a country, depending on market segment and clusters in relation with visitors' profiles.

\section{Social media in rural tourism marketing strategies}

Previous studies of rural tourism marketing regarding marketing strategies have focused mostly on promotion channels (CHEN et al., 2013). Based on studies conducted by LEE et al. (2003) and LUBETKIN (1999), owner-manager perceptions of the usefulness of various types of promotion were ranked as follows by CHEN et al. (2013): (1) Word of mouth (WOM), (2) Brochures, (3) Chambers of Commerce, (4) Mobile and AAA guidebooks, (5) B\&B guidebooks and (6) Websites, while B\&B guests ranked them as (1) WOM, (2) B\&B guidebooks, (3) mobile and AAA guidebooks, (4) Magazines and newspapers, (5) Travel agencies and (6) Websites. Although, there is a difference in the ranking in supply and demand, it is obvious that the most effective type of promotion is WOM. For instance, in a case study conducted in Norway, WOM was reported to be the most effective marketing channel perceived (NORDBØ, 2009). According to another case study in Lithuania, 65\% of the guests obtained information on rural tourism farms through WOM (friends, acquaintances, relatives and colleagues) and made their decision to choose a particular farm/destination based on their recommendation (RAMANAUSKIENÉ \& 
RAMANAUSKAS, 2006). More recent studies also indicated the same, but a change has occurred in the shape of the WOM advertisement. Traditional WOM has turned into e-WOM and influence marketing has emerged (CHATZIGEORGIOU,2017) as a result of easier and cheaper access to technology and the internet. Technology and the internet have fundamentally changed the way of communication and interaction between business and customers (KELLER, 2009; PATO \& KASTENHOLZ, 2017). This is even more important for a product and/or service spatially isolated from its markets, such as rural tourism (CLARKE, 2005; HERNÁNDEZ-MAESTRO \& GONZÁLEZBENITO, 2013; GÖSSLING \& LANE, 2015; PATO \& KASTENHOLZ, 2017), and requires tourists to be attracted from external markets (CLARKE, 1999; FYALL \& GARROD, 2004; SAXENA, 2016; PATO \& KASTENHOLZ, 2017). This fact makes social networking, media, internet and marketing influences more important in attracting people to visit rural areas. The social networking philosophy is based on the quick dissemination of information with the active participation of users who have the opportunity to exchange or share an idea, a thought, a message or an opinion with one to many others (BIZIRGIANNI \& DIONYSOPOULOU, 2013). Having an instant share of an internet phenomenon or marketing influence affects its followers more than any other tools in their decision and behaviour. This especially occurs among the Netizen Generation or "Network Citizens", who are characterized by a propensity to exchange information through computers, tablets and mobiles, who get opinions by influences in the virtual world (PARK et al., 2010; KOTLER et al., 2017). This has become a business and a form of marketing, where the advertising focuses on specific individuals with a large number of followers. SAMMIS et al. (2016) described it as "the art and science of engaging people who are influential online to share brand messaging with their audiences in the form of sponsored content" (CHATZIGEORGIOU, 2017). For instance, a study which explored how young people planned a trip in terms of information sources, influence by social media and activities reported that $89 \%$ out of 225 respondents chose the internet as their first option for planning their trip (BIZIRGIANNI \& DIONYSOPOULOU, 2013).

No one who wants to survive in the marketing business should ignore this fact. Therefore, this study analysed the motivation and satisfaction of visitors to one of the newest rural tourism areas of Turkey, which is linked to social media and marketing influences.

\section{Methodology for data collection and analysis}

The main data of the study was collected through questionnaires. The questionnaire was given online and addressed to people who visited Kuyucak village. This approach was chosen because it was assumed that the main driver of the visitor was images of the village shared online and that social media was the main source of the information. The survey was administered in one month in July 2018, as the best time for visiting the lavender fields is June and July. The questionnaire was promoted through social media tools by the authors and the coordinator of the Lavender Scented Village Project. The first part of the questions was about the demographic and personal characteristics of the visitors, and the second part aimed to identifying visitors' motivations behind their visit, and their link to information sources for hearing, making decisions, planning and visiting. We had also questions in this part regarding their level of satisfaction with several factors, and also their overall satisfaction. The questions were prepared with multiple choice answers, and all items for motivation and satisfaction were rated using a 7-point Likert scale. An open question was asked only for evaluating their suggestions for future measures that should be taken for sustainability and good marketing strategies, and the answers obtained from this question were based for developing marketing mix with an accompanying experts' consultation.

The total number of valid surveys included in the analysis was 175 . In order to test the adequacy of sampling for further analysis, the Kaiser-MeyerOlkin (KMO) measure was performed and reported to be $0.88(>0.70)$, which indicated that factor analysis is appropriate for this sample (KAISER, 1960; CHEN et al. 2013, KASTENHOLZ et al. 2018). The data analysis was completed using SPSS 23.0 at descriptive and inferential level as follows: (1) Descriptive statistics were calculated for all surveys; (2) Items with Likert Scale were classified through factor analysis in order to identify motivation factors; (3) Respondents were clustered arbitrarily according to their different features, such as place of origin, motivation, information source and income level;(4) In order to complete the analysis, the results collected from visitors answers were discussed with practitioners and academics on several related issues including lavender production, rural tourism, agro-food marketing and rural development in the region. 


\section{RESULTS AND DISCUSSION}

The study was conducted in the lavender area in Kuyucak village in the district of Keçiborlu in Isparta province in the Southwest part of Turkey (Figure 1) because the area has been newly developed in terms of rural tourism based on lavender tourism. In addition to the natural beauty of lavender, other supporting factors for rural tourism in the study area can be listed as follows: the proximity of main roads, local interests and a grassroots movement, and public awareness. According to the descriptive analysis, the profile of the sample was formed predominantly by female respondents $(73 \%)$; less than $3 \%$ were educated to primary school level, and the rest were highly educated (college and above). The average age was 34 . It was reported that $57 \%$ of the respondents lived outside Isparta, and the greatest number were from Istanbul (24\%), Antalya (24\%) or Ankara (14\%) (Table 1). Kuyucak is about $150 \mathrm{~km}$ from Antalya, $390 \mathrm{~km}$ from Ankara and $550 \mathrm{~km}$ from Istanbul. Most of the visitors from outside Isparta (91\%) came only for the purpose of visiting Kuyucak; only $9 \%$ of them came for other purposes and came to Kuyucak when they were already in Isparta. Also, $19 \%$ of the respondents had visited Kuyucak more than once. No one had visited the village before 2016, before it was promoted as the Lavender Scented Village.

Cronbach's coefficient was calculated for the reliability of the measurement of expressions and variables by Likert Scale. It resulted in a robust value for the overall set $(0.88)$ and for each of the items (0.80-0.89). As it exceeded the minimum level of 0.70 , it was reliable (CHEN et al., 2013; DEVESA et al., 2010). Visitors were asked about their knowledge and behaviour regarding their trip. According to the results presented in Table 2, a majority of the visitors $(82 \%)$ already had rural tourism experience and most of them $(60 \%)$ had paid a touristic visit to a rural area more than five time. Only about $6 \%$ of the visitors had gone to Kuyucak alone, and among those who went with a group (94\%), most went with a group of friends $(51 \%)$, family $(39 \%)$ or a tour $(9 \%)$. Most of the visitors (74\%) preferred to stay in Kuyucak for just a few hours, the rest either spent a day there but did not stay overnight (11\%), or stayed overnight $(14 \%)$ with acquaintances (39\%), in a hotel in Isparta $(35 \%)$, or in a B\&B in Kuyucak $(12 \%)$. This was because there is not enough activity for spending a day in Kuyucak, nor are there accommodation facilities. Results clearly showed the power of the social media on people as an information source and influencer, in that more than half of the respondents had heard about the village and got information on it via social media. Although, the main purpose of their visit was stated as nature/rural experience by $49 \%$ and recreation/holiday by $47 \%$, the primary motivation of $46 \%$ of the visitors was taking and sharing photos (Figure 2). Lavender appearance and previous social media sharing were very important determinants in

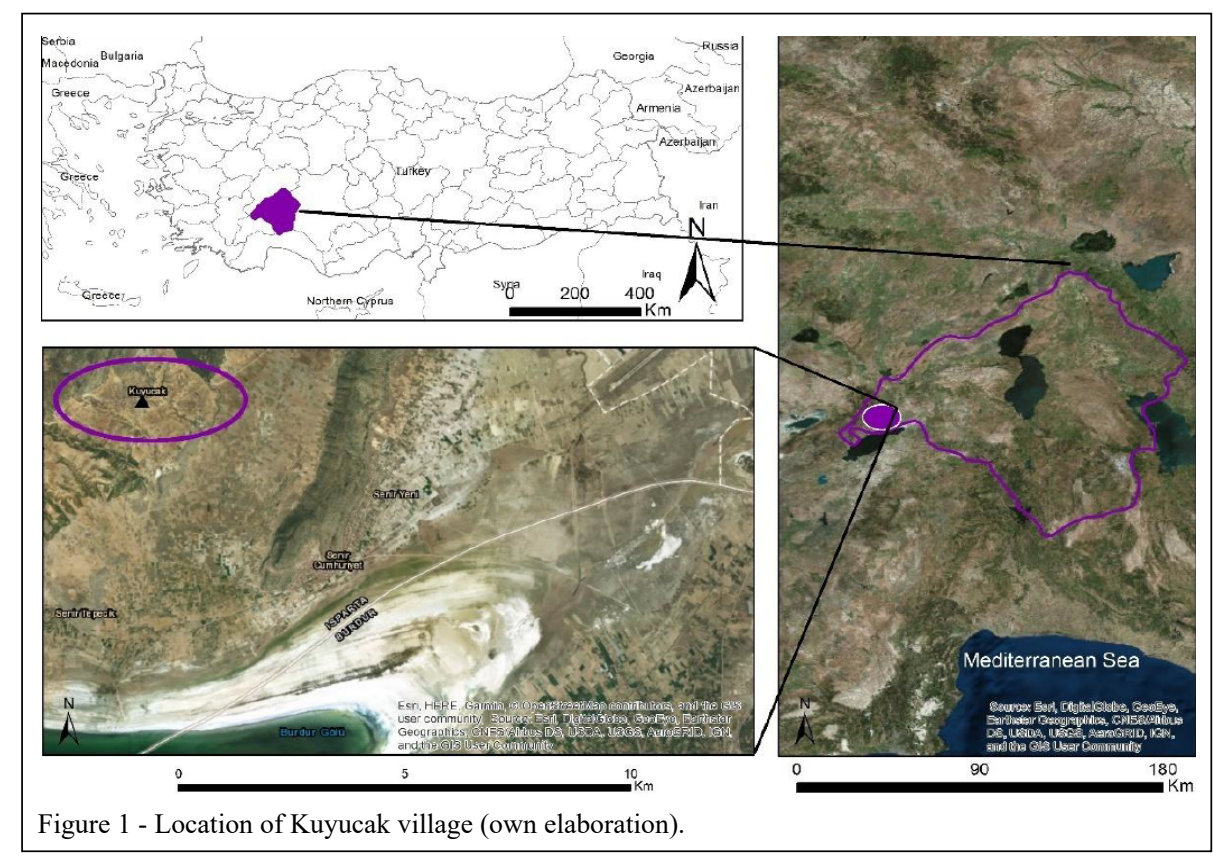

Ciência Rural, v.49, n.2, 2019. 
Table 1 - Profile of the visitors

\begin{tabular}{lcc}
\hline Variable & Frequency & Percent $(\%)$ \\
\hline Gender & & \\
Male & 47 & 26.9 \\
Female & 128 & 73.1 \\
\hline Age & & \\
$17-30$ & 80 & 45.7 \\
\hline $31-40$ & 51 & 29.1 \\
\hline $41-50$ & 32 & 18.3 \\
\hline $51-60$ & 12 & 6.9 \\
\hline Education & & \\
Primary school & 5 & 2.9 \\
\hline High school & 14 & 8.0 \\
College & 18 & 10.3 \\
Bachelor's degree & 83 & 47.4 \\
\hline Master's degree & 42 & 24.0 \\
\hline PhD & 13 & 7.4 \\
\hline Income (unit: TL) & & \\
\hline No income & 20 & 11.9 \\
\hline <=5000 & 120 & 71.9 \\
\hline $5001-10000$ & 23 & 13.8 \\
\hline$>=10000$ & 4 & 2.4 \\
\hline
\end{tabular}

the decision-making of visitors and in increasing their expectations and motivation to visit.

In order to explore the variables affecting visitors' satisfaction, a factor analysis was performed. As applied in similar previous studies based on the suggestion by HAIR et al. (1998), items with a factor loading of above 0.5 were retained to increase construct validity (CHEN et al., 2013). Two components with eigenvalues above 1 were extracted from nine variables. The first component was named pre-visit perception and motivation and the second component was named physical evidence, and together they explained $65 \%$ of the overall satisfaction of the visitors. What was found interesting was the component on their perception before visiting $(53 \%)$, which means that what they expected to see was more important than what they saw, which was represented by the component on physical conditions $(12 \%)$ on visitors' satisfaction (Table 3$)$. Lavender appearance and previous social media sharing were very important determinants in the decision-making of visitors and their expectations.

Based on the opinions and suggestions of the visitors who were involved in the questionnaire in consultation with experts, a marketing mix was developed for achieving sustainable rural tourism marketing in Kuyucak through creating the highest visitor satisfaction.

Kotler defines marketing mix as a set of controllable variables that the firm can use to influence buyer "response" (SAEIDI POUR et al., 2013). In the classic marketing mix, these controllable variables refer to product, price, place and promotion; although, there are alternative approaches and additional parameters. Classic marketing mix, known as 4Ps, has been adapted to tourism marketing in order to maximize economic benefits through attracting people who become visitors (JIA \& XIAOBING, 2017).

Based on the classic marketing mix variables, figure 3 illustrates how Kuyucak village should manage its source in order to maximize visitors' satisfaction level. Target market was defined according to the profile of the visitors in the study. Although, there are visitors of all ages, they are mostly young people, highly educated, in the middle or lower income level, using social media actively, travelling with family or a group, and usually visiting not for a day but only for few hours because of lack of accommodation and extra activities in Kuyucak. DRAGI DIMITROVSKI et al. (2012) also highlighted a similar profile in their study referring that this type of visitors is open to typical rural activities including farm works, as well as enjoying nature and gastronomy.

Products and services were defined as basic, usable, expected, extended and potential at five levels (KOTLER \& KELLER, 2012). Basic products provide basic benefits to visitors when they purchase them and/or stay in rural areas. In our case, lavender fields, farming activities, local and traditional food and thematic photography are basic products which have appeared recently there. The first motivation for people to go to Kuyucak is lavender plantations. Lavender appearance and previous social media sharing which is called pre-visit perception in the study were very important determinants in the decision-making of visitors and in increasing their expectations and motivation to visit. POWER et al. (2005) defined destination image as a sum of beliefs, ideas and impressions which people have of a place or destination and described the less difference perceived between a destination's images and actual image, the more satisfied visitors with the destination. This is why it is a starting point, but it needs to be developed in order to obtain congruence between visitors' previsit perception and actual service, product and image provided during their visit. This brings a question of how to determine these services, products and services. Marketing mix is a helpful tool for providers 
Table 2 - Visitors' responses regarding their knowledge and behaviour on their visit

\begin{tabular}{|c|c|c|}
\hline Question & Response & Percent \\
\hline \multicolumn{3}{|c|}{ Had you heard about rural tourism before? } \\
\hline & Yes & 81.1 \\
\hline & No & 18.9 \\
\hline \multicolumn{3}{|c|}{ Where did you hear about rural tourism? } \\
\hline & Social media & 56.3 \\
\hline & TV/newspaper & 11.3 \\
\hline & Academic studies & 6.3 \\
\hline & Travel agencies & 6.3 \\
\hline & Acquaintances & 5.6 \\
\hline \multicolumn{3}{|c|}{ Have you engaged in rural tourism previously? } \\
\hline & Yes & 82.3 \\
\hline & No & 17.7 \\
\hline \multicolumn{3}{|c|}{ If yes, how many times have you taken part in rural tourism? } \\
\hline & $1-5$ & 40.3 \\
\hline & $5+$ & 59.7 \\
\hline \multicolumn{3}{|c|}{ Where did you first hear about the lavender fields and Kuyucak? } \\
\hline & Social media & 58.3 \\
\hline & Acquaintances & 25.7 \\
\hline & TV/newspaper & 13.7 \\
\hline \multicolumn{3}{|c|}{ Where did you get your information about Kuyucak? } \\
\hline & Social media & 59.4 \\
\hline & Acquaintances & 24.6 \\
\hline & TV/Newspaper & 13.7 \\
\hline \multicolumn{3}{|c|}{ What is the main purpose of your visit? } \\
\hline & Nature/rural experience & 48.6 \\
\hline & Recreation/holiday & 47.4 \\
\hline \multicolumn{3}{|c|}{ What is the main motivation behind your trip? } \\
\hline & Taking and sharing photos & 46.3 \\
\hline & Curiosity & 46.3 \\
\hline \multicolumn{3}{|c|}{ Did you come to Kuyucak alone or with a group? } \\
\hline & Alone & 5.7 \\
\hline & Group & 94.3 \\
\hline \multicolumn{3}{|c|}{ If a group, with... } \\
\hline & Family & 50.9 \\
\hline & Friends & 38.8 \\
\hline & Tour & 8.5 \\
\hline \multicolumn{3}{|c|}{ How long did your visit to Kuyucak take? } \\
\hline & A few hours & 73.7 \\
\hline & A day (overnight stay) & 13.7 \\
\hline & A day (no overnight stay) & 11.4 \\
\hline \multicolumn{3}{|c|}{ Where did you stay? } \\
\hline & Acquaintances & 38.5 \\
\hline & Hotel in Isparta & 34.6 \\
\hline & Bed\&breakfast in Kuyucak & 11.5 \\
\hline
\end{tabular}

in this regard. People who visit the area expect a larger lavender field and in a better shape. Most of the visitors complained about the very poor range of foods. The current situation with strong promotion is enough to bring people to Kuyucak but not enough to make them stay longer or re-visit. There needs to be an improvement in the infrastructure such as toilets and parking places, which are defined as usable 


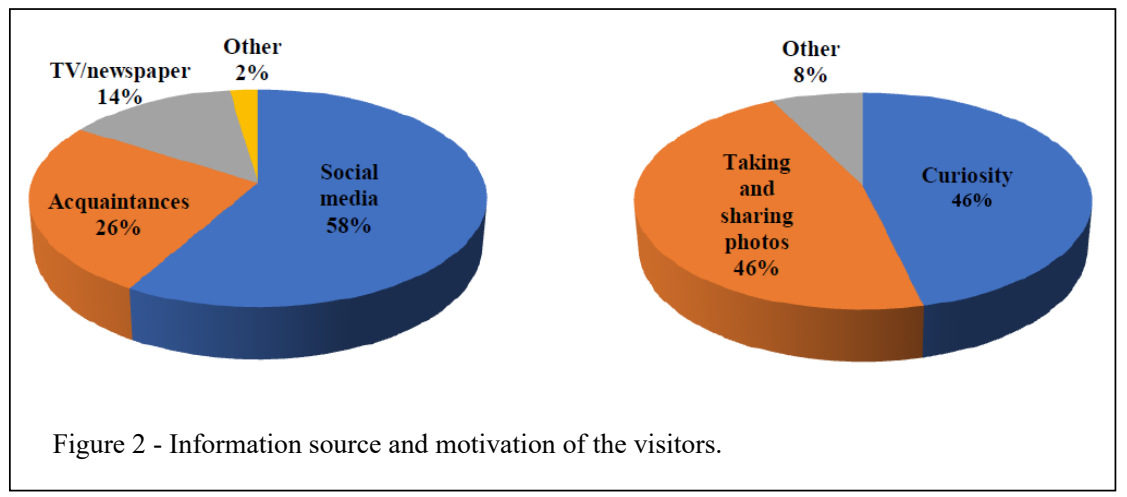

products, in addition to basic products. Expected products are what visitors expects while buying: style, quality, and a clean and quiet environment. In the study, the target market expected pleasant and environmentally friendly countryside cafes, restaurants, picnic places, quality and diversified local food and lavender products in addition to their first expected product, the large lavender plantations. Visitors were not happy with plastic plates and cutlery; they expected proper service utensils, a wooden table set and more elegant presentation. They also underlined the importance of traditional hospitality as an expectation. In fact, it makes sense also, as it can be achieved more easily than the other products and without any investment and training, and helps to compensate for the lack of the others in the short term. Friendliness of local people was also described an important complementary factor in rural tourism from the local communities' perspectives in different cultures (LO et al., 2012) and host-guest relations have been reported to significantly increase the quality of rural experience (KASTENHOLZ et al., 2018). Previous studies where positioning rural tourism were investigated suggested that among the different dimensions of rural areas, visitors should look for culture associated with localness which plays an important role in rural tourism destination. LO et al. (2012) used four dimensions (environment, social,

Table 3 - Factors influencing visitors' satisfaction.

\begin{tabular}{|c|c|c|c|c|c|c|c|c|c|}
\hline \multirow[b]{2}{*}{ Variables } & \multicolumn{3}{|c|}{----------Initial Eigenvalues---------- } & \multicolumn{2}{|c|}{ Components ${ }^{*}$} & \multirow[t]{2}{*}{$\begin{array}{c}\text { Cumulative } \\
\%\end{array}$} & \multirow[t]{2}{*}{ Total } & \multirow[t]{2}{*}{$\begin{array}{c}\% \text { of } \\
\text { Variance }\end{array}$} & \multirow[t]{2}{*}{$\begin{array}{c}\text { Cumulative } \\
\%\end{array}$} \\
\hline & Total & $\begin{array}{c}\% \text { of } \\
\text { Variance }\end{array}$ & $\begin{array}{c}\text { Cumulative } \\
\%\end{array}$ & 1 & 2 & & & & \\
\hline 1 & 4.783 & 53.141 & 53.141 & 692 & & 53.141 & 3.833 & 42.593 & 42.593 \\
\hline 2 & 1.085 & 12.057 & 65.198 & 864 & & 65.198 & 2.034 & 22.606 & 65.198 \\
\hline 3 & 836 & 9.292 & 74.491 & 427 & & & & & \\
\hline 4 & 637 & 7.079 & 81.570 & & 788 & & & & \\
\hline 5 & 595 & 6.614 & 88.184 & & 696 & & & & \\
\hline 6 & 377 & 4.187 & 92.370 & 680 & & & & & \\
\hline 7 & 279 & 3.095 & 95.465 & 813 & & & & & \\
\hline 8 & 254 & 2.820 & 98.285 & & & & & & \\
\hline 9 & 154 & 1.715 & 100.000 & & & & & & \\
\hline
\end{tabular}

Extraction Method: Principal Component Analysis.

'Component 1: Factors regarding visitors' perception and motivation factors.

Component 2: Factors regarding physical conditions of the village. 
cultural and economics) and only cultural dimension was reported to be statistically significant.

Extended products are additional services, benefits and activities and are defined as extra activities, courses, workshops and similar events which may include exhibitions of lavender oil distillation, cultural tours, and art and craft training for Kuyucak. The final item represents the future direction of business development and environmental concerns and is called potential product. In the case of Kuyucak, lavender, lavender oil production, SPA, Turkish baths, beauty and care, good agricultural practices and organic production were defined as the potential which can be developed as additional value-added products and services in the future. This not only contributes to the socio-economic development of the village through sustainable rural tourism, but also helps the local people to position themselves in a further part of the lavender value chain, the lavender essential oil business. In fact, local people are fundamental component and suppliers in rural tourism marketing. Previous studies suggested that sustainable rural tourism cannot be achieved without local participation and positioning dimension should be determined locally (LO et al., 2012). As the tourism activity has developed very quickly, there are currently a very limited number of products and they are of low quality. ESMAILI et al. (2017) investigated the relationship between some elements of marketing mix with loyalty, perceived quality and destination image and reported that price in marketing mix had a positive impact on quality and loyalty while it had negative impact on the destination image. In the present study, visitors stated that there was no balance between quality and price. In fact, different things are happening regarding pricing. On the one hand, local people are not familiar with service marketing, and some of them do not see it as a commercial enterprise. They accept the visitors as their own guests, offer food, drinks, and even

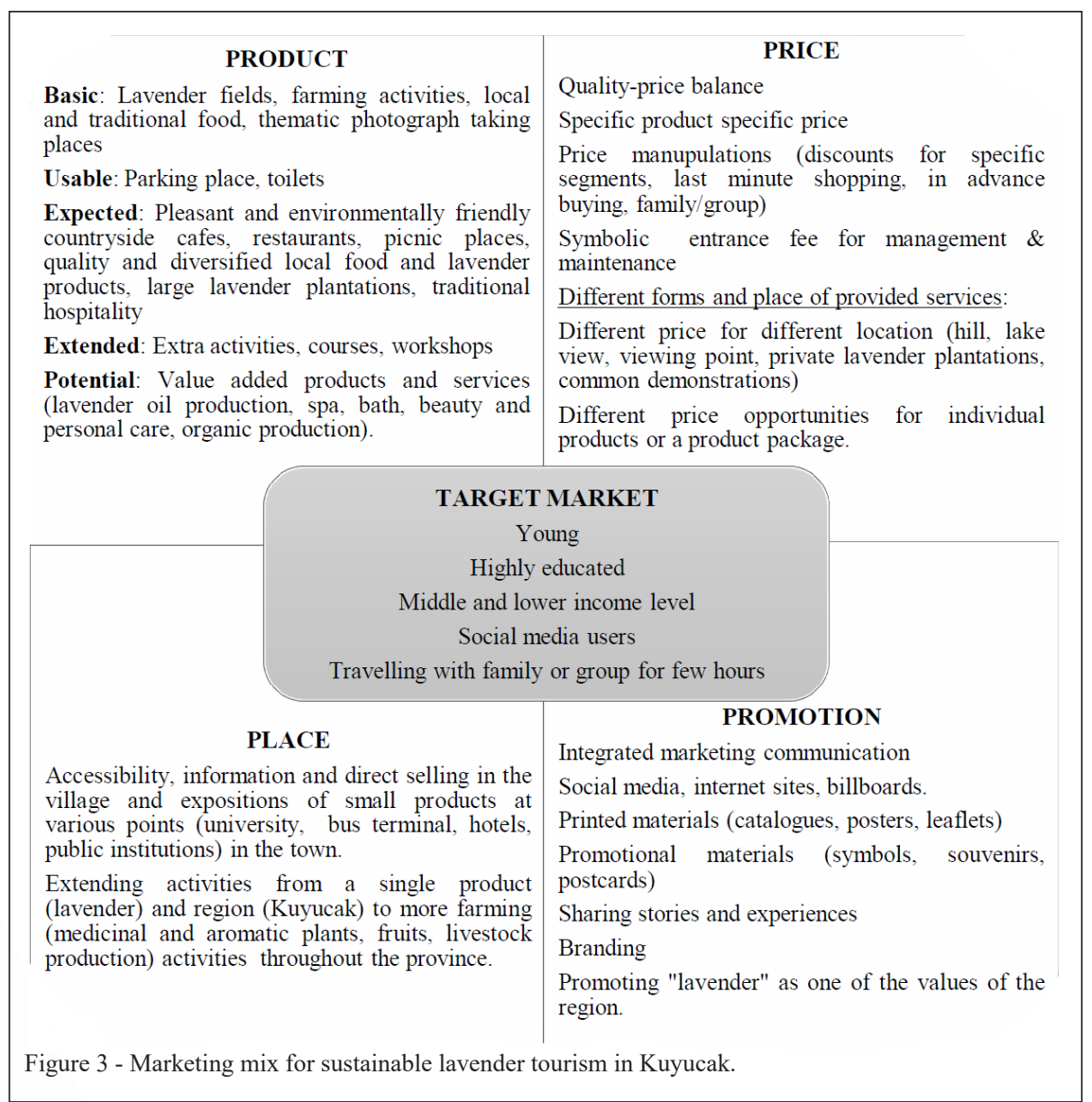

Ciência Rural, v.49, n.2, 2019. 
bed and breakfast. Conversely, there are some opportunists who abuse the lack of organization. In general; however, people are tending to improve new businesses, organizing themselves into a cooperation and considering the visitors' requirements for the future. When they diversify products, pricing strategy will be more important. They can use price manipulations for discounts for specific segments, last minute shopping, advance buying, and for families and groups. As majority of the people who go to Kuyucak with a family or group, different forms of services and places where they are provided should be considered for individuals as a product package. Currently there are no entrance fees in any lavender field. Sometimes visitors even enter private plantations, collect lavender and take pictures, and this may cause a problem in the future. In order to avoid any problems and for the management and maintenance of the lavender fields, it is recommended that a very low entrance fee should be charged for the village, and demonstration areas should be set up for visitors.

"Place" in marketing mix refers to distribution. Even though rural tourism marketing activities mostly occur at the location, the place component of marketing mix combines the rural area where tourism takes place and the distribution channels, including information on all products and ways to offer them. However, focusing only a place in rural tourism marketing will lead to a product-oriented perspective which ignores the delivery of experiences, because it is not about the marketing of a place but the provision of a collection of experiences (MIHAILOVIĆ \& MORIC, 2012; GILBERT, 1989). ESMAILI et al. (2017) reported that distribution (place) had no effect on the lack of activities related to the distribution of tourist attraction in the loyalty to the Khalkhal tourist destination image while it had effects on perceived quality. There are also other studies where the place was not approved as an important variable to effect on perceived quality (HUANG \& SARIGÖLLÜ, 2012). A holistic and strategic approach must be used in order to develop a whole product or services, or a better concept particularly in the marketing of a rural area. This approach is not only necessary from the marketing point of view but also for sustainable development.

This approach may apply to not only to Kuyucak but throughout the province of Isparta, through extending rural tourism as a whole portfolio including medicinal and aromatic plants, fruits, and livestock production activities. In the study, it was reported that Kuyucak is far from this vision, but by using right support tools and leadership, villagers are able to cooperate and work together.

It was also reported that visitors in Kuyucak did not know how and where to access information and products and/or services. They are mostly guided by the social media, which is not always objective in providing access or accepting whatever they find in the village. It is mostly directed towards selling in the village, and bunches of lavender from Kuyucak are only sold in one of the largest hypermarket chains during July and August. Some lavender products, like soaps, sachets, crowns etc. have been sold in small shops in Isparta for the past few years but they are not produced in Kuyucak. It is also possible to exhibit small products and souvenirs produced from the village in various places (university, bus terminal, hotels, public institutions) in the town in order to remind people of Kuyucak to make it visible to people who visit the town for other purposes.

Currently, the strongest component in the marketing mix of lavender-based rural tourism in Kuyucak is promotion. It is not only in our case but also previous studies also reported similar experiences. For instance, PATO \& KASTENHOLZ (2017) reported that the only action moderately developed by suppliers in rural tourism was in the domain of communication with the market while the other variables (product, place and price) of marketing mix were not fully developed and even neglected in some cases.

The promotion in Kuyucak village is done mostly through social media and influencers. Previous studies also underlined the importance of social media in promoting rural tourism. Particularly young people need to be approached in their own terms of communication and it is social media. They trust in influencer marketing, personal expression through social media posts and remarks and activities presented using photos and videos (CHATZIGEORGIOU, 2017). In our study, some celebrities have also visited the village and it boosted tourism as influencers in social media. The influencer marketing is a tool of viral marketing that can be of great use to those who are new in rural tourism marketing business and not competent to promote their own business (CHATZIGEORGIOU, 2017). However, in order to achieve sustainable rural tourism marketing, it is necessary to use all marketing communications. Social media and the internet are effective promotion tools but there are also risks of under estimation or overestimation, which may end up with disappointment and reverse in the same way. 
Indeed, some of the visitors have already complained that the photographs used for the promotion of the area in the social media were different from what they saw. POLO PEÑA et al. (2016) suggested that rural tourism providers must pay particular attention to the information they need to transfer to potential visitors regarding the product (image) they want to promote through their web-sites. By providing proper information and images, they will not only avoid underestimation or overestimation but also use their resources more efficiently (POLO PEÑA et al., 2016) and for branding. This is why it is necessary to pay attention the images presented by the popular mass media and consider how they relate to rural tourism (AITHAL \& ANIL, 2008).An appropriate design of the marketing mix dimensions also helps to achieve more competitive rural territories and conditions for the settlement of active population segments as complementary objectives (DINIS, 2006; PATO \& KASTENHOLZ, 2017).Previous studies also concluded that it is possible to develop strategies to increase the number of visitors and improve the rural tourism sector, and these elements can also play a valuable role in creating a positive state of visitors' minds through an appropriate marketing mix (SERYASAT et al., 2014).

For sustainable rural tourism in Kuyucak or anywhere, marketing should not be implemented as only a simple promotion, but as a platform for defining business objectives and strategies, and for producing goods and services which deliver a unique experience to visitors and create added value for a rural tourism destination (MIHAILOVIĆ \& MORIC, 2012)Taking the advantage of the supporting factors in the region and with a good management, benefits from rural tourism will contribute to increasing the socio-economic level of the village, women's empowerment, and the development of rural arts and crafts, to decreasing and reversing migration, and to the preservation and promotion of cultural heritage and rural development. These positive changes through rural tourism can lead to a multiplier effect in the region. However, there are also missing factors and challenges to be considered: the lack of extra activities and accommodation in order to extent visitors' stays in the village, the short tourism season, the lack of product diversification and quality, poor infrastructure facilities, the lack of trained human resources, and threats to the environment and cultural heritage in the case of mismanagement.

\section{CONCLUSION AND IMPLICATIONS}

This study started with the motivation to understand what was happening in a small village with 250 habitants, why many people go there in crowds, and how it became a trend in just three years to visit this village and share a picture in a lavender field. It was an investigation of how people were so easily motivated to go there, what they expected while they were going, and whether they came back happy, or in other words whether it was going to be sustainable.

The study highlights the fact that there is an increasing demand for the lavender village thanks to a grassroots movement of initiation and support at a local and national level, but social media contribution in revitalization is prominent. Apparently, the attractive images of lavender fields and stories shared on social media by other people and especially marketing influencers (famous people, celebrities, "phenomena") has created a perception in would-be visitors, and those who make the trip with higher motivation get higher satisfaction; although, the village does not meet all their expectations in terms of physical conditions and activities. The results of the study and observations in the region can be interpreted in this way: taking into account the advantages of this phenomenon and the beauty of the lavender, there is a need to develop good marketing strategies which consider visitors' opinions in order to make it sustainable. First, a cooperative and diversified marketing is essential at regional level, as the duration of the lavender season is very short and activities related to lavender cultivation are limited. This also requires strong networks where many activities related to rural tourism can take place in the region without pressure on natural resources, involving all stakeholders in the business.

The study has contributed to the areas of research and practice. As the case study region currently became popular and there is no scientific study conducted, there is lack of knowledge. Sometimes its popularity may create a disinformation and mislead people both suppliers and buyers. As a first study discussing the rural tourism marketing in the area the study yields important implications for rural development research. An implication for rural tourism practitioners that can be learnt from this study is how important to design an appropriate marketing mix for the sustainability of their business is. As most of the rural tourism practitioners are rural people who has no experience in service marketing, providing training and helping them became more important and will develop implication to the society.

Finally, a few limitations of the research should be drawn. The main limitation was restricted time for the field study. We believed that it had to be carried out during the lavender season in case visitors were not able to remember details of their experiences or were not interested in participation if we conducted out of the season. Lavender season is only two months during the summer and it is too crowded for face to face interviews. 
This is why we applied an online survey which also has its own limitations. We had a small sample size to generalize the results to the other rural tourism destination. However, it is a fundamental study for future discussion but bearing in mind that it provides only a static perspective and additional studies are needed. Empirical case studies as a starting point are important at this stage and there is still room for future studies on both demand and supply sides for drafting marketing strategies.

\section{BIOETHICS AND COMMITTEE APPROVAL \\ BIOSECURITY}

We, the authors of the article entitled "Rural tourism marketing: Lavender tourism in Turkey" declare, for all due purposes, that the project that gave rise to the present data of the same has not been submitted for evaluation to the Ethics Committee of Isparta University of Applied Sciences, but we are aware of the contents of Resolution No. 466, of December 12, 2012 of the Brazilian National Health Council "http://conselho.saude.gov.br/resolucoes/2012/ Reso466.pdf' if it involves human beings. Thus, the authors assume full responsibility for the presented data and are available for possible questions, should they be required by the competent authorities.

\section{DECLARATION OF CONFLICTING INTERESTS}

The authors declare that there is no conflict of interest.

\section{AUTHORS' CONTRIBUTIONS}

FHG was the main contributor to the study, conduct the research design, methodology and prepared questionnaire. The statistical analysis of the data was conducted by BK. FHG, BK and AGAB prepared the draft of the manuscript and critically revised the manuscript. All authors approved of the final version.

\section{REFERENCES}

AITHAL, R.K.; ANIL, R.K. Concept, application and marketing in rural tourism. Indian Institute of Management Kozhikode, 2008/4/5. Available from <http://dspace.iimk.ac.in/bitstream/ handle/2259/106/RM150.pdf? sequence $=1 \&$ is Allowed $=y>$. Accessed: Sept. 18, 2018.

ANTUNES, J. et al. Can rural tourism satisfy Portuguese tourist's needs? Examining Portuguese tourist's preferences. In tourism engagement: co-creating well-being. Proceedings of the 6th Advances in Tourism Marketing Conference, p. 38-43, 2015. Available from <http://repositorio.ipv.pt/ bitstream/10400.19/4135/1/1.1.7.\%20Proceedings\%20ATMC turismo\%20rural.pdf>. Accessed: Sept. 18, 2018.

BASARAN, N. Bringing lavender to economy in rural development and rural tourism scope, Research Journal of Agricultural Sciences, E-ISSN: 1308-027X, v.10, n.1, p.47-49, 2017. Available from <http://dergipark.gov.tr/download/article-file/430469>. Accessed: Sept. 18, 2018

BIZIRGIANNI, I.; DIONYSOPOULOU, P. The Influence of Tourist Trends of Youth Tourism Through Social Media (SM) \&
Information and Communication Technologies (ICTs). ProcediaSocial and Behavioral Sciences, v.73, p.652-660, 2013. Available from: <https://doi.org/10.1016/j.sbspro.2013.02.102>. Accessed: Nov. 1,2018. doi: https://doi.org/10.1016/j.sbspro.2013.02.102

BotTen, N.; MCMANUS, J. Competitive Strategies For Service Organisations. Purdue University Press, 1999.

BOZKIRAN, S.; GIRAY, F.H. Lavender production and marketing in Isparta. In: XI. Agricultural Economists Congress, 3-5 September, 2014, Samsun, Turkey. Proceedings Book. Samsun: UTEK, 2014. p.1365-1368. Available from: <http://www.tarimarsiv.com/wpcontent/uploads/2017/04/239-242.pdf>. Accessed: Sept. 18, 2018.

BOZKIRAN, S.; GIRAY, F.H. Structural analysis of lavender farms. In: XII. Agricultural Economists Congress, 25-28 May, 2016, Isparta, Turkey. Proceeding Book. Isparta: UTEK, 2016. p.1857-1864. Available from: <http:/www.tarimarsiv.com/wpcontent/uploads/2017/04/41.pdf>. Accessed: Sept. 18, 2018.

CAI, L.A. et al. Identifying rural tourism markets: a practical tool, Journal of Hospitality \& Leisure Marketing, v.17,n.3/4, p.418-434, 2008. Available from: <https://https://doi. org/10.1080/10507050801985153>. Accessed: Nov.1, 2018. doi:10.1080/10507050801985153.

CHATZIGEORGIOU, C. Modelling The Impact of Social Media Influencers on Behavioural Intentions of Millennials: The Case of Tourism in Rural Areas İn Greece. Journal of Tourism, Heritage \& Services Marketing, v.3, n.2, p.25-29, 2017

CHEN, L. et al. Rural tourism: Marketing strategies for the bed and breakfast industry in Taiwan. International Journal of Hospitality Management, v.32, p.278-286, 2013. Available from: $<$ https://doi.org/10.1016/j.ijhm.2012.07.005>. Accessed: Nov. 1, 2018. doi:10.1016/j.ijhm.2012.07.005.

CLARKE, J. Marketing structures for farm tourism: beyond the individual provider of rural tourism. Journal of Sustainable Tourism, v.7, n.1, p.26-47, 1999. Available from: <https://doi. org/10.1080/09669589908667325>. Accessed: Nov. 1, 2018. doi:10.1080/09669589908667325.

CLARKE, J. Effective Marketing for Rural Tourism, Rural Tourism and Sustainable Business, Channel View Publications, Clevedon, United Kingdom, 2005.

DRAGI DIMITROVSKI, D. et al. Rural tourism and regional development: Case study of development of rural tourism in the region of Gruža, Serbia. Procedia Environmental Sciences. v.14, p.288-297, 2012. Available from: <https:// www.researchgate.net/publication/257728308 Rural Tourism_and_Regional_Development_Case_Study_of_Development_of_Rural_Tourism_in_the_Region_of Grua_Serbia $>$. Accessed: Dec. 20, 2018. doi:10.1016/j. proenv.2012.03.028.

DEVESA, M. et al. The role of motivation in visitor satisfaction: Empirical evidence in rural tourism. Tourism Management, v.31, n.4, p.547-552, 2010. Available from: <https://doi.org/10.1016/j. tourman.2009.06.006>. Accessed: Nov. 1, 2018. doi:10.1016/j. tourman.2009.06.006.

DINIS, A. Marketing and innovation: Useful tools for competitiveness in rural and peripheral areas, European Planning Studies, v.14, n.1, p.9-22, 2006. Available from: <https://doi. 
org/10.1080/09654310500339083>. Accessed: Nov. 1,2018. doi: https://doi.org/10.1080/09654310500339083.

DONCEAN, M. The creative-inventive use of colors in rural tourism marketing strategy, Lucrări Ştiinţifice, seria Agronomie, v.56, n.2, p.213-216, 2013. Available from: <http://www.uaiasi.ro/ revagrois/PDF/2013-2/paper/2013-56(2)_40-en.pdf $>$. Accessed: Nov. 1, 2018.

ESMAILI, S. et al. The Impact of Marketing Mix on Perceived Value, Destination Image and Loyalty of Tourists (Case Study: Khalkhal City, Iran). Modern Applied Science, v.11, n.11, p.96, 2017. Available from: <https://doi.org/10.5539/ mas.v11n11p96>. Accessed: Nov. 1, 2018. doi:10.5539/mas. v11n $11 \mathrm{p} 96$.

FYALL, A.; GARROD, B. Tourism marketing: A collaborative approach v.18. Channel View Publications, 2004.

GHADIRI, M. et al. Evaluation and Prioritization of Indicators Effective in Marketing of Rural Tourism with Marketing Mix Model 7p; Case Study: Selected Cities of Mazandaran Province. Quarterly Journal of Urban and Rural Management, v.32, p.139-152 (in Persian), 2013.

GILBERT, D. Rural Tourism and Marketing: Synthesis and new ways of working, Tourism Management, p.39-50, 1989. Available from: <https://doi.org/10.1016/0261-5177(89)90033-2>. Accessed: Nov. 1, 2018. doi:10.1016/0261-5177(89)90033-2.

GÖSSLING, S.; LANE, B. Rural Tourism and the Development of Internet - Based Accommodation Booking Platforms: A Study in The Advantages, Dangers and Implications of Innovation. Journal of Sustainable Tourism, 2015. Available from: <https://doi.org/ 10.1080/09669582.2014.909448>. Accessed: Nov. 1,2018. doi: https://doi.org/10.1080/09669582.2014.909448

GUL, M. et al. Determining costs and profitability of lavender farms in Isparta province of Turkey. Journal of Essential Oil Bearing Plants, v.19, n.3, p.686-692, 2016. Available from: $<$ https://doi.or g/10.1080/0972060X.2014.971074>. Accessed: Nov. 1, 2018. doi: 10.1080/0972060X.2014.971074.

HAIR, J.F., et al. Multivariate Data Analysis. Upper Saddle River, 1998.

HERNÁNDEZ-MAESTRO, R. M.; GONZÁLEZ-BENITO, Ó. Rural Lodging Establishments as Drivers of Rural Development. Journal of Travel Research, v.53, n.1, p.83-95, 2013. Available from: <https://doi.org/10.1177/0047287513481273>. Accessed: Nov. 1,2018. doi: https://doi.org/10.1177/0047287513481273

HUANG, R.; SARIGÖLLÜ, E. How brand awareness relates to market outcome, brand equity, and the marketing mix. Journal of Business Research, 65, 92-99, 2012. Available from $<$ https://doi. org/10.1016/j.jbusres.2011.02.003>. Accessed: dec.18, 2018.

JIA, C.;XIAOBING, C. Research on Framework of Rural Tourism Marketing Model Based on the Marketing Combination Theory, Revista de la Facultad de Ingeniería, v.32, n.16, p. 73-79, 2017.

HUANG, R.; SARIGÖLLÜ, E. How brand awareness relates to market outcome, brand equity, and the marketing mix. Journal of Business Research, 65, 92-99, 2012. Available from $<$ https://doi. org/10.1016/j.jbusres.2011.02.003>. Accessed: Dec. 18, 2018
KAISER, H. F. The application of electronic computers to factor analysis. Educational and Psychological Measurement, v.20, p.141-151, 1960. Available from: <https://doi.org/1 0.1177/001316446002000116>. Accessed: Nov. 1, 2018. doi: $10.1177 / 001316446002000116$

KASTENHOLZ, E. et al. The dimensions of rural tourism experience: impacts on arousal, memory, and satisfaction. Journal of Travel \& Tourism Marketing, v.35, n.2, p.189-201, 2018. Available from: $<$ https://doi.org/10.1080/10548408.2017.1 350617>. Accessed: Nov. 1, 2018. doi:10.1080/10548408.2017 .1350617 .

KELLER, K. L. Building strong brands in a modern marketing communications environment. Journal of marketing communications, v.15, n.2-3, 139-155, 2009.Available from: $<$ https://doi.org/10.1080/13527260902757530>. Accessed: Nov. 1, 2018. doi.org/10.1080/13527260902757530.

KOTLER, P. et al. Marketing 4.0: Moving from Traditional to Digital, ISBN 978-605-2261-03-3, Optimist Yayın Grubu No: 454, Istanbul, Turkey. 2017.

KOTLER, P.; KELLER, K.L. Marketing Management, 2012. 658p. Available from <https://www.academia.edu/34196971/ Marketing_Management 14th_Edition - Kotler and Keller. pdf>. Accessed: Dec. 19, 2018.

LEE, S. Y. et al. Bed and breakfast industries: Successful marketing strategies. Journal of Travel \& Tourism Marketing, v.14 n.1, p.37-53, 2003. Available from: $<$ https://doi.org/10.1300/ J073v14n01_03>. Accessed: Nov. 1,2018. doi: https://doi. org/10.1300/J073v14n01_03.

LO, M-C. et al., 2012. Positioning Rural Tourism: Perspective from the local communities. International Journal of Trade, Economics and Finance, Vol. 3, No. 1, February 2012. Available from $<$ http://www.ijtef.org/papers/173-T00022.pdf $>$. Accessed: Dec. 19, 2018.

LUBETKIN, M. Bed-and-Breakfasts: Advertising and Promotion. Cornell Hotel and Restaurant Administration Quarterly, v.40, n.4, p.84-90, 1999. Available from: <https://doi.org/10.1177/001088049 904000418>. Accessed: Nov. 1,2018. doi: https://doi. org/10.1177/001088049904000418

MCCARTHY, J. E. Basic marketing-a managerial approach. Illinois: Irwin, 1960. 770p.

MIHAILOVIĆ, B.; MORIC, I. The role of marketing philosophy in rural tourism development. Tourism and Hospitality Management, v.18, n.2, p.267-279, 2012.

NORDBØ, I. Living with Tourism: The Case of Small-scale Rural Tourism Businesses in Norway and Chile (Doctoral dissertation, Aalborg University).2009.

PARK, D. B.; YOON, Y. S. Segmentation by motivation in rural tourism: A Korean case study. Tourism Management, v.30, n.1, p.99-108.2009.

PARK, M. et al. Tourism and the N Generation in a Dynamically Changing Society: the Case of South Korea. In: BENCKENDORFF, P. et al (Eds). Tourism and Generation Y. FSC Mixed Source, p.85-97. 2010. 
PATO, L.; KASTENHOLZ, E. Marketing of rural tourism-a study based on rural tourism lodgings in Portugal. Journal of Place Management and Development, v.10, n.2, p.121-139.2017.

PAVEL, C. Implementation of Marketing in Rural Tourism. Quaestus Multidisciplinary Research Journal, v.1, n.2, p.3642.2013.

POLO PEÑA et al. Online Marketing Strategy and Market Segmentation in the Spanish Rural Accommodation Sector. Journal of Travel Research 2016. Vol. 55(3) 362-379.Available from <https://journals.sagepub.com/ doi/10.1177/0047287514546224>.

POWER, J. et al. Developing the positioning of the Irish rural tourism product-the role of image and market focus. Presented at the Tourism \& Hospitality Research in Ireland: Exploring the Issues Conference, University of Ulster 14th - 15th June 2005, University of Ulster, Belfast, Northern Ireland. Available from <https://repository.wit. ie/472/>. Accessed: Dec. 182018.

PUAD MAT SOM, A. et al. Shopping motivation factors at tourist night markets, Journal of Tourism, v.11, n.1, 2010. Available from $<$ https://www.researchgate.net/publication/328466108_Shopping Motivation_Factors_at_Tourist_Night_Markets_Dr_Ahmad_Puad_ Mat_Som>. Accessed: dec., 182018.

RAMANAUSKIENĖ, J., RAMANAUSKAS, J. Application of the principles of total quality management in the knowledge formation. Engineering Economics, v. 46, n.1, p. 1-7, 2006.

ROBERTS, L.; HALL, D. Consuming the countryside: Marketing for 'rural tourism'. Journal of Vacation Marketing, v.10, n.3, p.253-263.2004. Available from <https://journals.sagepub.com/ doi/pdf/10.1177/135676670401000305>. Accessed: Nov. 1, 2018. doi:10.1177/135676670401000305.

SAEIDI POUR, B. et al. 2013. The effect of marketing mix in attracting customers: Case study of Saderat Bank in Kermanshah Province. African Journal of Business Management 7(34):3272-3280. 2013 Available from < https://doi.org/10.5897/ AJBM12.127>. Accessed: Nov. 10 2018. doi:10.5897/ AJBM12.127.

SAMMIS, K. et al. Influencer Marketing for Dummies. New Jersey: John Wiley \& Sons, 2016.

SAXENA, G. Marketing rural tourism: Experience and Enterprise. Edward Elgar Publishing, Cheltenham. 2016.Available from: $<$ https://doi.org/10.4337/9781784710880>. Accessed: Nov. 1, 2018. doi: $10.4337 / 9781784710880$.

SERYASAT, M. R. et al. Analysis of factors affecting tourism marketing rural marketing mix model (P7) case study: district Baraghan. Advances in Environmental Biology, p.18101820.2014.<https://www.researchgate.net/publication/289323114 Analysis_of_factors_affecting_tourism_marketing_rural marketing_mix_model_P7_case_study_District_Baraghan $>$. Accessed: Nov. 10, 2018.

TURKSTAT. Turkish Statistical Institute Crop Production Statistics. <http://www.turkstat.gov.tr/PreTablo.do?alt_id=1001>. Accessed: Nov. 10, 2018.

UNDP. Future is in Tourism. Online information on the webpage of the project of Future is in Tourism, Available from $<$ http://www. tr.undp.org/content/turkey/en/home/projects/future-is-in-tourism. html>. Accessed: Aug. 10, 2018. 